Article

\title{
Preparative Separation of Spirobisnaphthalenes from Endophytic Fungus Berkleasmium sp. Dzf12 by High-Speed Counter-Current Chromatography
}

\author{
Tijiang Shan ${ }^{1}$, Shiqiong Lu ${ }^{1}$, Chao Luo ${ }^{1}$, Ruiya Luo ${ }^{1}$, Yan Mou ${ }^{1}$, Mingan Wang ${ }^{2}$, \\ Youliang Peng ${ }^{1}$ and Ligang Zhou ${ }^{1, *}$ \\ 1 MOA Key Laboratory of Plant Pathology, Department of Plant Pathology, \\ College of Agronomy and Biotechnology, China Agricultural University, Beijing 100193, China \\ 2 Department of Applied Chemistry, College of Science, China Agricultural University, \\ Beijing 100193, China \\ * Authors to whom correspondence should be addressed; E-Mail: lgzhou@cau.edu.cn; \\ Tel.: +86-10-6273-1199; Fax: +86-10-6273-1062.
}

Received: 8 July 2013; in revised form: 29 September 2013 / Accepted: 12 October 2013 / Published: 16 October 2013

\begin{abstract}
High-speed counter-current chromatography (HSCCC) was applied for the first time for the preparative separation of spirobisnaphthalenes from a crude extract of the endophytic fungus Berkleasmium sp. Dzf12, associated with the medicinal plant Dioscorea zingiberensis. Six spirobisnaphthalenes were successfully separated by HSCCC with a two-phase solvent system composed of $n$-hexane-chloroform-methanol-water (1.5:3.0:2.5:2.0, $\mathrm{v} / \mathrm{v}$ ). About $18.0 \mathrm{mg}$ of diepoxin $\mathrm{\kappa}(\mathbf{1}), 245.7 \mathrm{mg}$ of palmarumycin $\mathrm{C}_{13}$ (2), $42.4 \mathrm{mg}$ of palmarumycin $\mathrm{C}_{16}(\mathbf{3}), 42.2 \mathrm{mg}$ of palmarumycin $\mathrm{C}_{15}$ (4), $32.6 \mathrm{mg}$ of diepoxin $\delta(5)$, and $22.3 \mathrm{mg}$ of diepoxin $\gamma(6)$ with purities of 56.82, 71.39, 76.57, 75.86, 91.01 and $82.48 \%$, respectively, as determined by high-performance liquid chromatography (HPLC), were obtained from $500 \mathrm{mg}$ of the crude extract in a one-step elution within $7 \mathrm{~h}$ of separation procedure by HSCCC. The purified spirobisnaphthalenes were further structurally characterized by means of physicochemical and spectrometric analysis.
\end{abstract}

Keywords: preparative separation; spirobisnaphthalenes; endophytic fungus; Berkleasmium sp. Dzf12; high-speed counter-current chromatogrphy 


\section{Introduction}

Spirobisnaphthalenes (also namely bisnaphthospiroketals) are a growing group of fungal metabolites which contain two 1,8-dihydroxynaphthalene-derived spiroketal units bridged through a spiroketal linkage [1,2]. Spirobisnaphthalenes possess a wide range of biological properties, including antibacterial [3-5], antifungal [6,7], algicidal [4,8], antiplasmodial [9], nematicidal [10], antileishmanial [11], cytotoxic [9] and anti-tumor [12] activities. Some of these compounds have been identified as novel inhibitors of rasfarnesyltransferase [13], DNA gyrase [14], topoisomerase II [15] and thioredoxin-reductase [16,17], and thus are of interest in terms of their potential in cancer chemotherapy.

In our previous study, a variety of bioactive spirobisnaphthalenes were isolated from the endophytic fungus Berkleasmium sp. Dzf12 derived from the medicinal plant Dioscorea zingiberensis [7,18]. This fungus was also found to be a high producer of spirobisnaphthalenes [19-22]. In order to speed up investigation and application of spirobisnaphthalenes in agriculture, medicine and food industry [23], one of the most important issues is how to efficiently obtain spirobisnaphthalenes from the fungal cultures.

High-speed counter-current chromatography (HSCCC), a support-free liquid-liquid partition chromatographic technique, eliminates the problem of irreversible adsorption of the sample on the solid support, and it offers the maximum capacity with an excellent sample recovery [24]. Moreover, HSCCC permits direct introduction of crude samples into the column without additional sample preparation. It has been successfully applied to the analysis and separation of various natural products such as flavonoids [24-26], alkaloids [27-29], polyphenols [30], terpenoids [31-33], and quinones [34] from medicinal plants and microorganisms.

To the best of our knowledge, there is no previous report on the preparative separation of spirobisnaphthalenes from fungi. The purpose of this study was to establish a method for more efficient separation and purification of spirobisnaphthalenes from the endophytic fungus Berkleasmium sp. Dzf12 cultures by HSCCC. The separated spirobisnaphthalenes were further purified by Sephadex LH-20 chromatography and preparative HPLC, and structurally characterized by means of physicochemical and spectrometric analysis.

\section{Results and Discussion}

\subsection{HPLC Analysis of the Crude Extract}

The crude ethyl acetate extract from the endophytic fungus Berkleasmium sp. Dzf12 was first analyzed by HPLC. The main spirobisnaphthalenes were satisfactorily separated with methanol-water $(45: 55, \mathrm{v} / \mathrm{v})$ as the solvent system. The HPLC chromatogram of the ethyl acetate crude extract is shown in Figure 1. Peaks $a, b$, e and $f$ correspond to palmarumycin $C_{15}$ (4), diepoxin $\gamma$ (6), palmarumycin $\mathrm{C}_{13}(\mathbf{2})$, and diepoxin $\kappa(\mathbf{1})$, respectively. Peak $\mathrm{c}+\mathrm{d}$ was a mixture of diepoxin $\delta(\mathbf{5})$ and palmarumycin $\mathrm{C}_{16}(\mathbf{3})$. 
Figure 1. HPLC chromatogram of the ethyl acetate crude extract from endophytic fungus Berkleasmium sp. Dzf12. The retention times of peaks a-f were 13.28, 16.97, 18.54, 19.63, 21.13 and $27.34 \mathrm{~min}$, respectively.

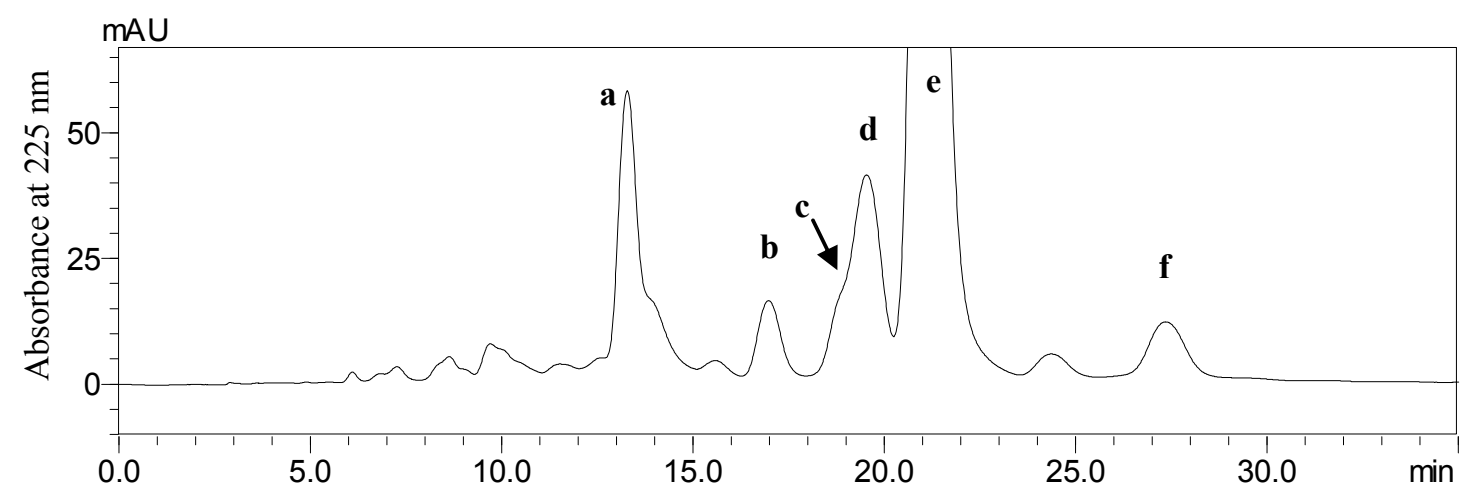

\subsection{Selection of Two-Phase Solvent System for HSCCC}

Successful separation by HSCCC largely depends upon the selection of a suitable two-phase solvent system, which was selected according to the partition coefficient ( $K$ value) of each target compound [35]. In general, an optimum $K$ value should be within the range of 0.5-2.0 [36,37]. A smaller $K$ value elutes the solute closer to the solvent front with lower resolution while a larger $K$ value tends to give better resolution but broader, and more dilute peaks due to a longer elution time [35]. In this study, different solvent systems containing $n$-hexane-chloroform-methanol-water were examined to optimize the $K$ values of the spirobisnaphthalenes by HPLC analysis. Their $K$ values are shown in Table 1 . The most appropriate $K$ value was obtained at the volume ratio of 1.5:3.0:2.5:2.0 (v/v), which was selected to further isolate and purify the spirobisnaphthalenes by HSCCC in the present study.

Table 1. The partition coefficients ( $K$ values) of spirobisnaphthalenes in the two-phase solvent systems of $n$-hexane-chloroform-methanol-water by HPLC analysis.

\begin{tabular}{ccccccc}
\hline \multirow{2}{*}{ No. } & \multirow{2}{*}{ Ratio (v/v) } & \multicolumn{5}{c}{$\boldsymbol{K}$ value } \\
\cline { 3 - 7 } & & Peak a & Peak b & Peak c+d & Peak e & Peak f \\
\hline 1 & $1.0: 3.0: 2.0: 2.0$ & 1.72 & 1.75 & 1.01 & 0.42 & 0.13 \\
2 & $1.5: 3.0: 2.0: 2.0$ & 2.11 & 2.32 & 1.74 & 0.77 & 0.46 \\
3 & $1.5: 3.0: 2.5: 2.0$ & 1.95 & 2.16 & 1.53 & 0.89 & 0.66 \\
4 & $1.5: 3.0: 1.5: 2.0$ & 2.01 & 2.19 & 1.61 & 0.64 & 0.45 \\
5 & $1.0: 3.0: 3.0: 2.0$ & 1.89 & 2.07 & 1.47 & 0.46 & 0.32 \\
\hline
\end{tabular}

Note: "Ratio" is expressed as the volume ratio of $n$-hexane-chloroform-methanol-water. Peaks a-f in HPLC chromatogram correspond to compounds $4,6,5,3,2$ and 1 , respectively.

\subsection{Separation of Spirobisnaphthalenes by HSCCC and Structural Identification}

The ethyl acetate extract of the endophytic fungus Berkleasmium sp. Dzf12 was fractionated by HSCCC using the optimized $n$-hexane-chloroform-methanol-water (1.5:3.0:2.5:2.0, v/v) solvent system. Seven peak fractions (i.e., I-VII) were obtained in one-step elution within $7 \mathrm{~h}$. The HSCCC chromatogram is shown in Figure 2. 
Figure 2. HSCCC chromatogram of the ethyl acetate crude extract from endophytic fungus Berkleasmium sp. Dzf12 with $n$-hexane-chloroform-methanol-water (1.5:3.0:2.5:2.0, v/v) solvent system.

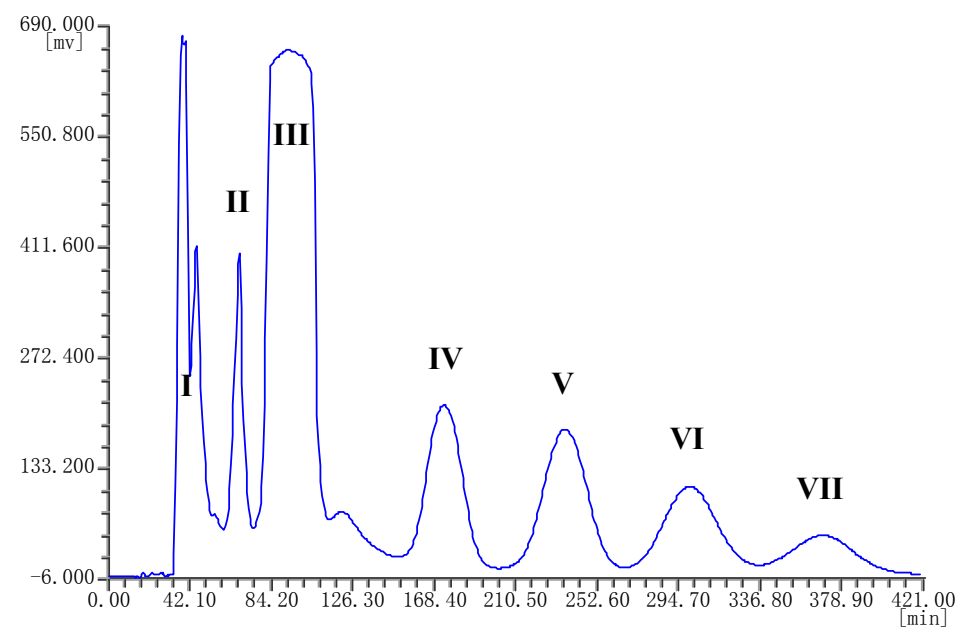

The separation was considered to be efficient with retention ratio $\left(S_{\mathrm{F}}\right)$ of the stationary phase to be $73.68 \%$. The HSCCC fractions were concentrated and further analyzed by HPLC which gave the chromatograms in Figure 3.

Figure 3. HPLC analysis and UV spectra of each HSCCC fraction. (A) diepoxin $\kappa(\mathbf{1})$ from HSCCC peak fraction II; (B) palmarumycin $\mathrm{C}_{13}$ (2) from HSCCC peak fraction III; (C) palmarumycin $\mathrm{C}_{16}$ (3) from HSCCC peak fraction IV; (D) palmarumycin $\mathrm{C}_{15}$ (4) from HSCCC peak fraction V; (E) diepoxin $\delta(\mathbf{5})$ from HSCCC peak fraction VI; (F) diepoxin $\gamma$ (6) from HSCCC peak fraction VII. The HPLC retention time of each HSCCC peak fraction (i.e., II-VII) was 27.48, 20.95, 19.15, 13.19, 18.87 and $16.92 \mathrm{~min}$, respectively.
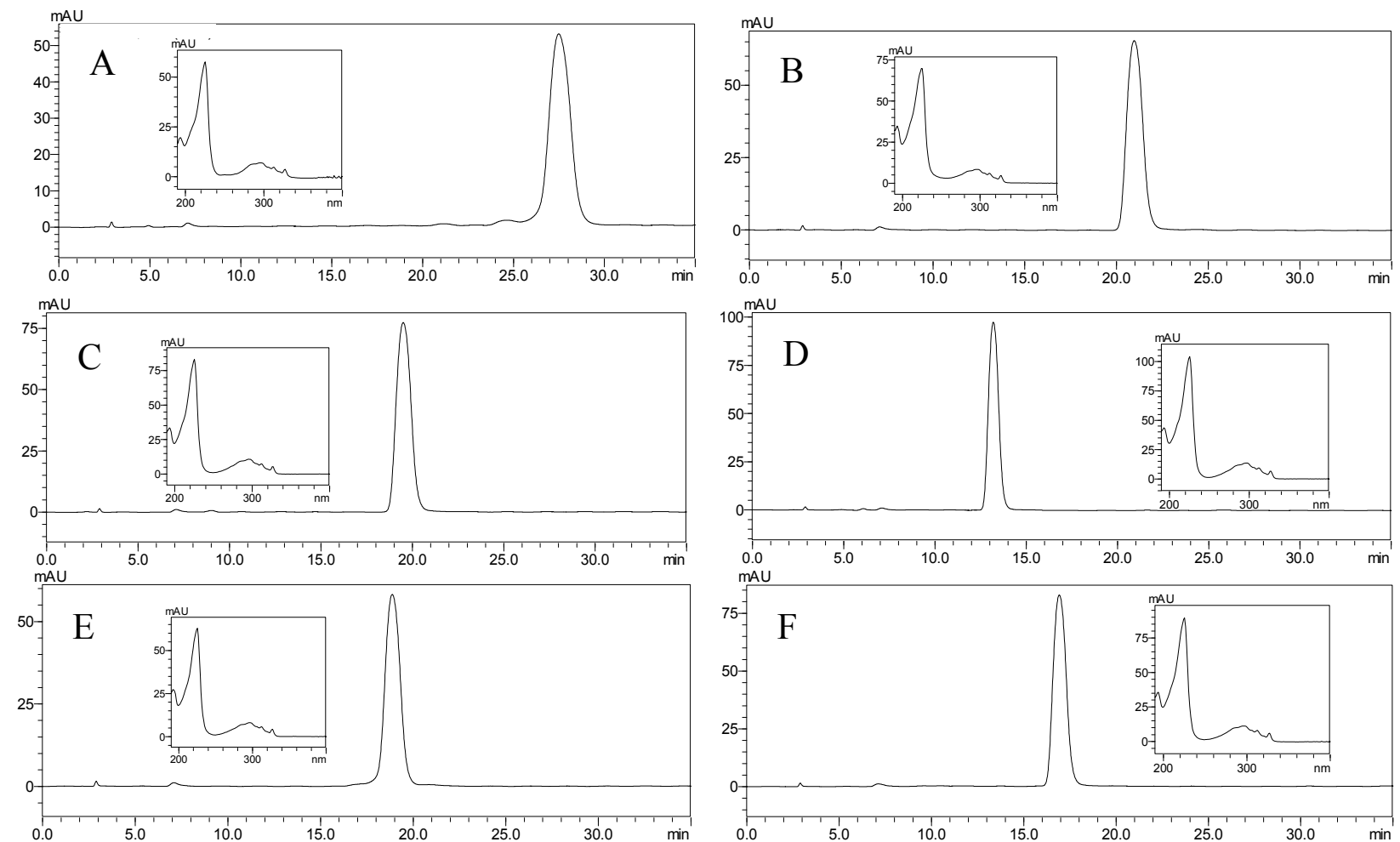
The HSCCC separation produced $18.0 \mathrm{mg}$ of compound 1 with $56.82 \%$ purity in peak fraction II, $245.7 \mathrm{mg}$ of compound 2 with $71.39 \%$ purity in peak fraction III, $42.4 \mathrm{mg}$ of compound 3 with $76.57 \%$ purity in peak fraction IV, $42.2 \mathrm{mg}$ of compound 4 with $75.86 \%$ purity in peak fraction $\mathrm{V}, 32.6 \mathrm{mg}$ of compound 5 with $91.01 \%$ purity in peak fraction VI, $22.3 \mathrm{mg}$ of compound 6 with $82.48 \%$ purity in peak fraction VII, respectively, from $500 \mathrm{mg}$ of crude ethyl acetate extract only in one HSCCC run. In addition, concentrated peak fraction I was $46.9 \mathrm{mg}$, and the residue in the solenoid was $34.9 \mathrm{mg}$. So the sample recovery was $97.0 \%$. After comparing their physicochemical and spectrometric data with those reported in the literatrure [4,38], the components were identified as diepoxin $\kappa(\mathbf{1})$, palmarumycin $\mathrm{C}_{13}$ (2), palmarumycin $\mathrm{C}_{16}(3)$, palmarumycin $\mathrm{C}_{15}$ (4), diepoxin $\delta(5)$, and diepoxin $\gamma(6)$, respectively, whose structures are shown in Figure 4. They are all belong to the deoxypreussomerin-type of spirobisnaphthalenes [2].

Figure 4. The structures of compounds $\mathbf{1}-\mathbf{6}$.
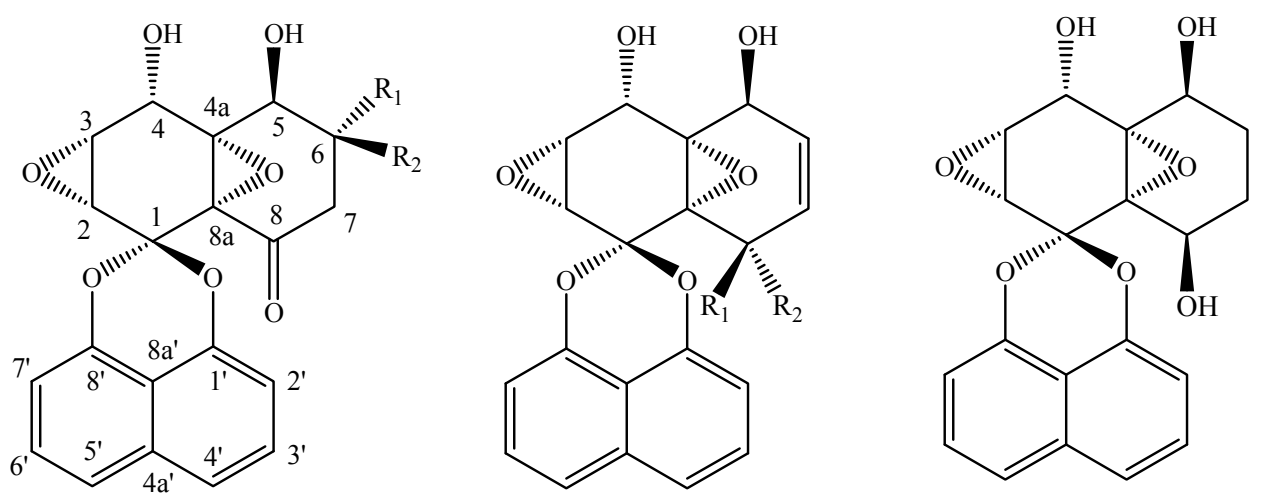

$$
\begin{array}{ll}
1 & \mathrm{R}_{1}=\mathrm{OCH}_{3}, \mathrm{R}_{2}=\mathrm{H} \\
5 & \mathrm{R}_{1}=\mathrm{OH}, \mathrm{R}_{2}=\mathrm{H} \\
\mathbf{6} & \mathrm{R}_{1}=\mathrm{H}, \mathrm{R}_{2}=\mathrm{OH}
\end{array}
$$

$$
\begin{array}{ll}
2 \mathrm{R}_{1}+\mathrm{R}_{2}=\mathrm{O} \\
4 \mathrm{R}_{1}=\mathrm{OH}, \mathrm{R}_{2}=\mathrm{H}
\end{array}
$$

\section{Experimental}

\subsection{General Analytical Methods}

Preparative HSCCC was carried out with a model TBE-300B instrument (Tauto Biotech, Shanghai, China). The apparatus was equipped with a polytetrafluoroethylene tube (diameter of tube was $2.6 \mathrm{~mm}$, and total volume was $280 \mathrm{~mL}$ ) composed of three preparative coils and a $20-\mathrm{mL}$ sample loop. The HSCCC system was equipped with a TBP-5002 pump and TBD-2000 UV detector operating at 280 $\mathrm{nm}$ (Tauto Biotech), and a WH500-USB workstation (Wuhao, Shanghai, China). The experimental temperature was $25^{\circ} \mathrm{C}$ adjusted by $\mathrm{HX}-1050$ constant temperature circulating implement (Boyikang, Beijing, China).

The analytical HPLC system (Shimadzu, Kyoto, Japan) consisted of two LC-20AT solvent delivery units, an SIL-20A autosampler, an SPD-M20A photodiode array detector, and CBM-20Alite system controller. Chromatographic separations were performed at $30{ }^{\circ} \mathrm{C}$ using Synergi reversed-phase Hydro- $\mathrm{C}_{18}$ column $(250 \mathrm{~mm} \times 4.6 \mathrm{~mm}, 5 \mu \mathrm{m}$, Phenomenex, Torrance, CA, USA). The mobile phase composed of methanol-water $(45: 55, \mathrm{v} / \mathrm{v})$ was eluted at a flow rate of $1.0 \mathrm{~mL} / \mathrm{min}$, and the effluent was 
monitored at $225 \mathrm{~nm}$. The LC solution multi-PDA workstation was employed to acquire and process chromatographic data. Total time of analysis was $35 \mathrm{~min}$.

The preparative HPLC system consisted of K-501 pump, K-2501 UV detector (Knauer, Berlin, Germany), a $2 \mathrm{~mL}$ sample loop, a workstation (Lumtech, Beijing, China), and an Ultimate XB reversed-phase $\mathrm{C}_{18}$ column $(21.2 \mathrm{~mm} \times 250 \mathrm{~mm}, 5 \mu \mathrm{m}$, Welch Materials, Inc., Maryland, MD, USA).

Sephadex LH-20 was purchased from Pharmacia Biotech, Uppsala, Sweden. HR-ESI-MS spectra were measured on Bruker Apex IV FTMS. NMR spectra $\left({ }^{1} \mathrm{H}-\mathrm{NMR}\right.$ and $\left.{ }^{13} \mathrm{C}-\mathrm{NMR}\right)$ were recorded on a Bruker Avance DRX-400 NMR spectrometer $\left({ }^{1} \mathrm{H}\right.$ at $400 \mathrm{MHz}$ and ${ }^{13} \mathrm{C}$ at $100 \mathrm{MHz}$ ). The chemical shifts were expressed in ppm as $\delta$ values relative to tetramethylsilane (TMS) as an internal standard. Thin layer chromatography (TLC) plates were coated with $0.5-\mathrm{mm}$ layers of silica gel $\left(\mathrm{GF}_{254}, 300-400\right.$ mesh, Qingdao Marine Chemical Company, Qingdao, China). The melting point was determined on an XT4-100B microscopic melting-point apparatus (Tianjin Tianguang Optical Instruments Company, Tianjin, China).

\subsection{Chemicals and Reagents}

All organic solvents used for sample preparation and HSCCC were of analytical grade and purchased from Beijing Chemical Company (Beijing, China). Methanol used for preparative and analytical HPLC was chromatography grade and was purchased from Xilong Chemical Company (Guangdong, China). Water used was distilled. Other chemicals were of analytical reagent grade.

\subsection{Preparaton of Crude Sample}

The endophytic fungus Dzf12 was isolated from the medicinal plant Dioscorea zingiberensis and was identified as Berkleasmium sp. Dzf12 (accession number DQ280463 in the GenBank) through its morphological characteristics and internal transcribed spacer (ITS) rRNA gene sequence analysis [7]. It was stored both on PDA slants at $4{ }^{\circ} \mathrm{C}$ and in $40 \%$ glycerol at $-70{ }^{\circ} \mathrm{C}$ in the Herbarium of the College of Agronomy and Biotechnology, China Agricultural University (Beijing, China). The fungus was cultured on PDA (potato $200 \mathrm{~g} / \mathrm{L}$, dextrose $20 \mathrm{~g} / \mathrm{L}$ and agar $20 \mathrm{~g} / \mathrm{L}$ ) medium in Petri dishes at $25{ }^{\circ} \mathrm{C}$ for 10 days. For seed culture, two to three plugs of agar medium $(0.5 \mathrm{~cm} \times 0.5 \mathrm{~cm})$ with fungal cultures were inoculated in each $250 \mathrm{~mL}$ Erlenmeyer flask containing $100 \mathrm{~mL}$ potato dextrose broth (PDB) medium, and incubated on a rotary shaker at $150 \mathrm{rpm}$ and $25{ }^{\circ} \mathrm{C}$ for 5 days. For fermentation culture, about 50 mycelia pellets were inoculated in each $1 \mathrm{~L}$ Erlenmeyer flask containing $300 \mathrm{~mL}$ PDB medium, and incubated on a rotary shaker at $150 \mathrm{rpm}$ and $25^{\circ} \mathrm{C}$ for 15 days. Afterwards, a total of $10 \mathrm{~L}$ fermentation broth was harvested.

The mycelia were separated from the culture filtrate by filtration and dried and powdered, and then extracted for three times with methanol. The dried methanol extract was suspension with water and extracted with ethyl acetate for three times. The culture filtrate was concentrated and also extracted three times with ethyl acetate. All the ethyl acetate extractions were concentrated under vacuum at $40{ }^{\circ} \mathrm{C}$ on a rotary evaporator to obtain the crude extract, and a total of $8.0 \mathrm{~g}$ crude extract was obtained. 


\subsection{Solvent Systems for HSCCC}

Two phase solvent systems containing different ratios of $n$-hexane, chloroform, methanol and water were prepared (Table 1). The partition coefficients ( $K$ values) were determined by HPLC and calculated according to the ratio of the compound concentration, $K=C_{\text {stationaryphase }} / C_{\text {mobilephase, where }}$

$C_{\text {stationary phase }}$ is the compound concentration in the stationary phase (upper phase), and $C_{\text {mobilephase }}$ is the compound concentration in the mobile phase (lower phase). As the volumes of the upper and lower phases of the pre-equilibrated two-phase solvent system are equal, the $\mathrm{K}$ values are then determined according the ratio of the peak area, $K=A_{\text {stationaryphase }} / A_{\text {mobilephase, }}$ where $A_{\text {stationaryphase }}$ is the peak area of the target compound in the stationary phase (upper phase), and $A$ mobilephase is the peak area of the target compound in the mobile phase (lower phase). The HPLC analysis was performed using a reversed-phase $\mathrm{C}_{18}(250 \mathrm{~mm} \times 4.6 \mathrm{~mm}, 5 \mu \mathrm{m})$ at $30{ }^{\circ} \mathrm{C}$. The elution system consisted of solvent $\mathrm{A}$ $(\mathrm{MeOH})$ and solvent $\mathrm{B}\left(\mathrm{H}_{2} \mathrm{O}\right)$ at the volume ratio of 45:55 (v/v), elution was done at $1.0 \mathrm{~mL} / \mathrm{min}$. UV detection was at $225 \mathrm{~nm}$.

\subsection{HSCCC Separation Procedure}

The $n$-hexane-chloroform-methanol-water $(1.5: 3.0: 2.5: 2.0, \mathrm{v} / \mathrm{v})$ solvent system was equilibrated at room temperature in a separatory funnel and the two phases were separated shortly before use. The coil column was first entirely filled with the stationary phase (the upper phase) of the solvent system. Then the apparatus was rotated at $850 \mathrm{rpm}$, while the mobile phase (the lower phase) was pumped into the column at a flow rate of $3 \mathrm{~mL} / \mathrm{min}$. After the mobile phase front emerged, and hydrodynamic equilibrium was established in the column, about $20 \mathrm{~mL}$ of sample solution containing $500 \mathrm{mg}$ of the ethyl acetate extract was injected through the injection valve. The effluent from the column outlet was monitored with a UV detector at $280 \mathrm{~nm}$ and fractions were collected manually according to the absorbance plot from the detector. The temperature of the apparatus was set at $25{ }^{\circ} \mathrm{C}$.

The retention ratio of stationary phase was also calculated, and the equation was as follows:

$$
S_{\mathrm{F}}(\%)=\frac{322-V_{\mathrm{S}}}{305-20} \times 100
$$

where $S_{\mathrm{F}}$ is the retention ratio of stationary phase (upper phase), and $V_{\mathrm{S}}$ is the volume of stationary phase flowing out. The yields were $46.9 \mathrm{mg}$ (yield $9.38 \%$ of the ethyl acetate extract) for peak fraction I, $18.0 \mathrm{mg}$ (yield 3.60\%) for peak fraction II, $245.7 \mathrm{mg}$ (yield 49.13\%) for peak fraction III, $42.4 \mathrm{mg}$ (yield 8.48\%) for peak fraction IV, $42.2 \mathrm{mg}$ (yield 8.44\%) for peak fraction V, $32.6 \mathrm{mg}$ (yield 6.53\%) for peak fraction VI, and $22.3 \mathrm{mg}$ (yield 4.46\%) for peak fraction VII, respectively. Fraction I was examined by thin layer chromatography (TLC) to be complicated with many minor compounds.

\subsection{Analysis and Identificaton of HSCCC Peak Fractions}

Each peak fraction separated by HSCCC was further purified by Sephadex LH-20 chromatography and preparative HPLC. The ethyl acetate crude extract and peak fractions separated by HSCCC were analyzed by HPLC. The linear equations of the compounds by HPLC analysis were as follows: $Y=9175440.8889 X-161194.4444\left(R^{2}=0.9993\right)$ (for diepoxin $\left.\kappa, 1\right), Y=7914352.2614 X+$ $17902.7516\left(R^{2}=0.9998\right)\left(\right.$ for palmarumycin $\left.C_{13}, 2\right), Y=9507067.6567 X-241729.0650\left(R^{2}=0.9986\right)$ 
(for palmarumycin $\left.\mathrm{C}_{16}, 3\right), Y=7659383.6667 X-71827.9417\left(R^{2}=0.9973\right)$ (for palmarumycin $\left.\mathrm{C}_{15}, 4\right)$, $Y=6701365.6667 X-59984.1917\left(R^{2}=0.9997\right)$ (for diepoxin $\left.\delta, \mathbf{5}\right), Y=7981014.8333 X+$ $108748.6042\left(R^{2}=0.9986\right)$ (for diepoxin $\gamma, 6$ ), where $Y$ was the peak area, $X$ was quality $(\mu \mathrm{g})$ of the sample injected for each time, and $R$ was the correlation coefficient. The physicochemical and spectrometric data of six spirobisnaphthalenes were given as follows.

Diepoxin $\kappa$ (1). White needle-like crystals (MeOH); m.p. 230-232 ${ }^{\circ} \mathrm{C}$; UV (MeOH) $\lambda_{\max } 225,297,312$, and $327 \mathrm{~nm}$. The molecular formula $\mathrm{C}_{21} \mathrm{H}_{18} \mathrm{O}_{8}$ was determined by HR-ESI-MS $\mathrm{m} / \mathrm{z} 416.1339$ $\left(\left[\mathrm{M}+\mathrm{NH}_{4}\right]^{+}\right.$, calcd for $\left.\mathrm{C}_{21} \mathrm{H}_{22} \mathrm{O}_{8} \mathrm{~N}, 416.1339\right) .{ }^{1} \mathrm{H}-\mathrm{NMR}$ (DMSO- $\left.d_{6}\right) \delta(\mathrm{ppm}): 7.63\left(1 \mathrm{H}, \mathrm{d}, J_{3^{\prime}, 4^{\prime}}=2.2\right.$ $\left.\mathrm{Hz}, \mathrm{H}-4^{\prime}\right), 7.61\left(1 \mathrm{H}, \mathrm{d}, J_{5^{\prime}, 6^{\prime}}=2.2 \mathrm{~Hz}, \mathrm{H}-5^{\prime}\right), 7.53 \quad\left[1 \mathrm{H}\right.$, pseudo-t (dd), $J_{2^{\prime}, 3^{\prime}}=7.7 \mathrm{~Hz}$, $\left.J_{3^{\prime}, 4^{\prime}}=8.2 \mathrm{~Hz}, \mathrm{H}-3^{\prime}\right], 7.50\left[1 \mathrm{H}\right.$, pseudo-t $(\mathrm{dd}), J_{5^{\prime}, 6^{\prime}}=7.8 \mathrm{~Hz}, J_{6^{\prime}, 7^{\prime}}=8.2 \mathrm{~Hz}, \mathrm{H}-6^{\prime}$ ], $7.08(1 \mathrm{H}, \mathrm{d}$, $\left.J_{2^{\prime}, 3^{\prime}}=7.4 \mathrm{~Hz}, \mathrm{H}-2^{\prime}\right), 7.04\left(1 \mathrm{H}, \mathrm{d}, J_{6^{\prime}, 7^{\prime}}=7.4 \mathrm{~Hz}, \mathrm{H}-7^{\prime}\right), 6.07\left(1 \mathrm{H}, \mathrm{d}, J_{5,5-\mathrm{OH}}=5.8 \mathrm{~Hz}, \mathrm{OH}-5\right), 5.91(1 \mathrm{H}$, $\left.\mathrm{d}, J_{4,4-\mathrm{OH}}=7.6 \mathrm{~Hz}, \mathrm{OH}-4\right), 4.76\left(1 \mathrm{H}, \mathrm{d}, J_{3,4}=5.8 \mathrm{~Hz}, \mathrm{H}-4\right), 4.35\left(1 \mathrm{H}, \mathrm{dd}, J_{5,6}=4.0 \mathrm{~Hz}, \mathrm{H}-5\right), 3.52-3.55$ (1H, m, H-6), $3.35(2 \mathrm{H}, \mathrm{d}, J=7.7 \mathrm{~Hz}, \mathrm{H}-2, \mathrm{H}-3), 3.27$ (3H, s, $\left.\mathrm{OCH}_{3}-9\right), 2.60-2.62$ (2H, m, H-7); ${ }^{13} \mathrm{C}-\mathrm{NMR}$ (DMSO- $\left.d_{6}\right) \delta(\mathrm{ppm}): 95.3$ (C-1), 52.6 (C-2), 55.2 (C-3), 60.9 (C-4), 70.1 (C-4a), 63.9 (C-5), 79.0 (C-6), 40.2 (C-7), $198.3(\mathrm{C}-8), 62.7$ (C-8a), $56.6\left(\mathrm{OCH}_{3}-9\right), 145.2\left(\mathrm{C}-\mathrm{l}^{\prime}\right), 109.1\left(\mathrm{C}-2^{\prime}\right), 127.8$ (C-3'), 120.7 (C-4'), 133.7 (C-4a'), 120.7 (C-5'), 127.7 (C-6'), 108.8 (C-7'), 145.5 (C-8'), 111.6 (C-8a'). The structure was confirmed by comparison with the literature data [38].

Palmarumycin $C_{13}$ (2). White needle-like crystals (MeOH); m.p. $162-164{ }^{\circ} \mathrm{C}$; UV (MeOH) $\lambda_{\max } 225$, 297, 312, and $327 \mathrm{~nm}$. The molecular formula $\mathrm{C}_{20} \mathrm{H}_{14} \mathrm{O}_{7}$ was determined by HR-ESI-MS $\mathrm{m} / z$ 405.0372 $\left([\mathrm{M}+\mathrm{K}]^{+}\right.$, calcd for $\left.\mathrm{C}_{20} \mathrm{H}_{14} \mathrm{O}_{7} \mathrm{~K}, 405.0372\right) .{ }^{1} \mathrm{H}-\mathrm{NMR}$ (DMSO-d $) \delta(\mathrm{ppm}): 7.64(1 \mathrm{H}, \mathrm{d}$, $\left.J=7.4 \mathrm{~Hz}, \mathrm{H}-4^{\prime}\right), 7.62$ (1H, d, $\left.J=7.4 \mathrm{~Hz}, \mathrm{H}-5^{\prime}\right), 7.49-7.60$ [2H, pseudo-t (dd), H-3', H-6'], 7.10 (1H, d, $\left.J=7.5 \mathrm{~Hz}, \mathrm{H}-2^{\prime}\right), 7.04\left(1 \mathrm{H}, \mathrm{d}, J=7.6 \mathrm{~Hz}, \mathrm{H}-7^{\prime}\right), 6.74(1 \mathrm{H}, \mathrm{dd}, J=4.9,10.5 \mathrm{~Hz}, \mathrm{H}-6), 6.24(1 \mathrm{H}, \mathrm{d}$, $J=7.8 \mathrm{~Hz}, \mathrm{OH}-4), 6.00(1 \mathrm{H}, \mathrm{d}, J=7.5 \mathrm{~Hz}, \mathrm{OH}-5), 5.88(1 \mathrm{H}, \mathrm{d}, J=2.2,10.5 \mathrm{~Hz}, \mathrm{H}-7), 4.98(1 \mathrm{H}, \mathrm{d}$, $J=7.6 \mathrm{~Hz}, \mathrm{H}-4), 4.67-4.70(1 \mathrm{H}, \mathrm{m}, \mathrm{H}-5), 3.17(2 \mathrm{H}, \mathrm{d}, J=5.2 \mathrm{~Hz}, \mathrm{H}-2, \mathrm{H}-3) ;{ }^{13} \mathrm{C}-\mathrm{NMR}$ (DMSO- $\left.d_{6}\right) \delta$ (ppm): 95.1 (C-1), 52.7 (C-2), 55.2 (C-3), 59.7 (C-4), 70.7 (C-4a), 60.6 (C-5), 125.3 (C-6), 144.8 (C-7), 188.8 (C-8), 62.2 (C-8a), 145.2 (C-1'), 109.1 (C-2'), 127.9 (C-3'), 120.7 (C-4'), 133.8 (C-4a'), 120.7 (C-5'), $127.7\left(\mathrm{C}-6^{\prime}\right), 108.7\left(\mathrm{C}-7^{\prime}\right), 145.5\left(\mathrm{C}-8^{\prime}\right), 111.5\left(\mathrm{C}-8 \mathrm{a}^{\prime}\right)$. The structure was confirmed by comparison with the literature data $[4,38]$.

Palmarumycin $C_{16}$ (3). Colorless waxy solid (MeOH); m.p. $187-188{ }^{\circ} \mathrm{C}$; UV (MeOH) $\lambda_{\max } 225,297$, 312, and $327 \mathrm{~nm}$. The molecular formula $\mathrm{C}_{20} \mathrm{H}_{18} \mathrm{O}_{7}$ was determined by HR-ESI-MS $\mathrm{m} / z$ 393.0944 $\left([\mathrm{M}+\mathrm{Na}]^{+}\right.$, calcd for $\left.\mathrm{C}_{20} \mathrm{H}_{18} \mathrm{O}_{7} \mathrm{Na}, 393.0945\right) .{ }^{1} \mathrm{H}-\mathrm{NMR}\left(\mathrm{CD}_{3} \mathrm{OD}\right) \delta(\mathrm{ppm}): 7.58\left(1 \mathrm{H}, \mathrm{d}, J_{3^{\prime}, 4^{\prime}}=8.2 \mathrm{~Hz}\right.$, H-4'), $7.55\left(1 \mathrm{H}, \mathrm{d}, J_{5^{\prime}, 6^{\prime}}=8.2 \mathrm{~Hz}, \mathrm{H}-5^{\prime}\right), 7.44-7.51\left(2 \mathrm{H}, \mathrm{m}, \mathrm{H}-3^{\prime}, \mathrm{H}-6^{\prime}\right), 7.11(1 \mathrm{H}, \mathrm{d}$, $\left.J_{2^{\prime}, 3^{\prime}}=7.4 \mathrm{~Hz}, \mathrm{H}-2^{\prime}\right), 7.02\left(1 \mathrm{H}, \mathrm{d}, J_{6^{\prime}, 7^{\prime}}=7.4 \mathrm{~Hz}, \mathrm{H}-7^{\prime}\right), 4.77\left(1 \mathrm{H}, \mathrm{d}, J_{3,4}=2.7 \mathrm{~Hz}, \mathrm{H}-4\right), 4.65(1 \mathrm{H}, \mathrm{m}$, $\mathrm{H}-8), 4.44(1 \mathrm{H}, \mathrm{m}, \mathrm{H}-5), 3.42\left(1 \mathrm{H}, \mathrm{d}, J_{2,3}=4.2 \mathrm{~Hz}, \mathrm{H}-2\right), 3.38\left(1 \mathrm{H}, \mathrm{dd}, J_{2,3}=4.3 \mathrm{~Hz}, J_{3,4}=2.8 \mathrm{~Hz}\right.$, H-3), 1.91 (2H, m, H-6eq, H-7eq), 1.45 (2H, m, H-6ax, H-7ax); ${ }^{13}$ C-NMR (CD 3 OD) $\delta$ (ppm): 98.1 (C-1), 53.7 (C-2), 56.9 (C-3), 62.9 (C-4), 69.0 (C-4a), 64.0 (C-5), 23.7 (C-6), 25.7 (C-7), 63.0 (C-8), 67.7 (C-8a), 147.4 (C-1'), $111.1 \quad\left(\mathrm{C}-2^{\prime}\right), \quad 128.8$ (C-3'), 122.2(C-4'), 135.6 (C-4a'), 122.2 $\left(\mathrm{C}-5^{\prime}\right), 128.6\left(\mathrm{C}-6^{\prime}\right), 110.2\left(\mathrm{C}-7^{\prime}\right), 147.7\left(\mathrm{C}-8^{\prime}\right), 114.0\left(\mathrm{C}-8 \mathrm{a}^{\prime}\right)$. The structure was confirmed by comparison with the literature data [4]. 
Palmarumycin $C_{15}$ (4). Colorless waxy solid (MeOH); m.p. $150-152{ }^{\circ} \mathrm{C}$; UV (MeOH) $\lambda_{\max } 225,297$, 312 , and $327 \mathrm{~nm}$. The molecular formula $\mathrm{C}_{20} \mathrm{H}_{16} \mathrm{O}_{7}$ was determined by HR-ESI-MS $\mathrm{m} / z$ 391.0784 $\left([\mathrm{M}+\mathrm{Na}]^{+}\right.$, calcd for $\left.\mathrm{C}_{20} \mathrm{H}_{16} \mathrm{O}_{7} \mathrm{Na}, 391.0789\right) .{ }^{1} \mathrm{H}-\mathrm{NMR}\left(\mathrm{CD}_{3} \mathrm{OD}\right) \delta(\mathrm{ppm}): 7.55(2 \mathrm{H}, \mathrm{d}$, $\left.J=8.4 \mathrm{~Hz}, \mathrm{H}-4^{\prime}, \mathrm{H}-5^{\prime}\right), 7.44-7.50$ (2H, m, H-3', H-6'), 7.09 (1H, d, $\left.J_{2^{\prime}, 3^{\prime}}=7.4 \mathrm{~Hz}, \mathrm{H}-2^{\prime}\right), 7.01$ (1H, d, $\left.J_{6^{\prime}, 7^{\prime}}=7.5 \mathrm{~Hz}, \mathrm{H}-7^{\prime}\right), 5.75\left(1 \mathrm{H}, \mathrm{dd}, J_{6,7}=10.4 \mathrm{~Hz}, J_{5,6}=4.5 \mathrm{~Hz}, J_{6,8}=1.7 \mathrm{~Hz}, \mathrm{H}-6\right), 5.57(1 \mathrm{H}$, dd, $\left.J_{6,7}=10.5 \mathrm{~Hz}, J_{7,8}=2.6 \mathrm{~Hz}, \mathrm{H}-7\right), 4.96(1 \mathrm{H}, \mathrm{s}, \mathrm{H}-8), 4.93\left(1 \mathrm{H}, \mathrm{d}, J_{3,4}=2.8 \mathrm{~Hz}, \mathrm{H}-4\right), 4.53(1 \mathrm{H}, \mathrm{d}$, $\left.J_{4,5}=4.5 \mathrm{~Hz}, \mathrm{H}-5\right), 3.47\left(1 \mathrm{H}, \mathrm{d}, J_{2,3}=4.3 \mathrm{~Hz}, \mathrm{H}-2\right), 3.42\left(1 \mathrm{H}, \mathrm{dd}, J_{2,3}=4.3 \mathrm{~Hz}, J_{3,4}=2.8 \mathrm{~Hz}, \mathrm{H}-3\right)$; ${ }^{13} \mathrm{C}-\mathrm{NMR}\left(\mathrm{CD}_{3} \mathrm{OD}\right) \delta(\mathrm{ppm}): 97.9$ (C-1), 54.4 (C-2), 57.1 (C-3), 62.6 (C-4), 68.9 (C-4a), 62.5 (C-5), 126.7 (C-6), 129.4 (C-7), 64.3 (C-8), 67.4 (C-8a), 147.3 (C-1'), 111.0 (C-2'), 128.9 (C-3'), 122.2(C-4'), $135.6 \quad\left(\mathrm{C}-4 \mathrm{a}^{\prime}\right), \quad 122.0 \quad\left(\mathrm{C}-5^{\prime}\right), \quad 128.6 \quad\left(\mathrm{C}-6^{\prime}\right), \quad 110.2 \quad\left(\mathrm{C}-7^{\prime}\right), \quad 147.7 \quad\left(\mathrm{C}-8^{\prime}\right), \quad 114.2 \quad\left(\mathrm{C}-8 \mathrm{a}^{\prime}\right)$. The structure was confirmed by comparison with the literature data [4].

Diepoxin $\delta(5)$. White needle-like crystals (MeOH); m.p. $241{ }^{\circ} \mathrm{C}$; UV (MeOH) $\lambda_{\max } 225,297,312$, and $327 \mathrm{~nm}$. The molecular formula $\mathrm{C}_{20} \mathrm{H}_{16} \mathrm{O}_{8}$ was determined by HR-ESI-MS $\mathrm{m} / \mathrm{z} 402.1180$ $\left(\left[\mathrm{M}+\mathrm{NH}_{4}\right]^{+}\right.$, calcd for $\left.\mathrm{C}_{20} \mathrm{H}_{20} \mathrm{O}_{8} \mathrm{~N}, 402.1183\right)$, and HR-ESI-MS $m / z 423.0473\left([\mathrm{M}+\mathrm{K}]^{+}\right.$, calcd for $\left.\mathrm{C}_{20} \mathrm{H}_{16} \mathrm{O}_{8} \mathrm{~K}, 423.0744\right) .{ }^{1} \mathrm{H}-\mathrm{NMR}\left(\mathrm{DMSO}-d_{6}\right) \delta(\mathrm{ppm}): 7.62\left(1 \mathrm{H}, \mathrm{d}, J_{3^{\prime}, 4^{\prime}}=8.0 \mathrm{~Hz}, \mathrm{H}-4^{\prime}\right), 7.60(1 \mathrm{H}, \mathrm{d}$, $\left.J_{5^{\prime}, 6^{\prime}}=8.0 \mathrm{~Hz}, \mathrm{H}-5^{\prime}\right), 7.48-7.55$ [2H, pseudo-t (dd), H-3', H-6'), 7.09 (1H, d, $\left.J_{2^{\prime}, 3}=7.5 \mathrm{~Hz}, \mathrm{H}-2^{\prime}\right), 7.05$ $\left(1 \mathrm{H}, \mathrm{d}, J_{6^{\prime}, 7^{\prime}}=7.5 \mathrm{~Hz}, \mathrm{H}-7^{\prime}\right), 5.94\left(1 \mathrm{H}, \mathrm{d}, J_{5,5-\mathrm{OH}}=5.7 \mathrm{~Hz}, \mathrm{OH}-5\right), 5.86\left(1 \mathrm{H}, \mathrm{d}, J_{4,4-\mathrm{OH}}=7.4 \mathrm{~Hz}, \mathrm{OH}-4\right)$, $5.04\left(1 \mathrm{H}, \mathrm{d}, J_{6,6-\mathrm{OH}}=5.6 \mathrm{~Hz}, \mathrm{OH}-6\right), 4.78\left(1 \mathrm{H}, \mathrm{d}, J_{3,4}=7.5 \mathrm{~Hz}, \mathrm{H}-4\right), 4.17-4.19(1 \mathrm{H}, \mathrm{m}, \mathrm{H}-5), 3.77-3.83$ $(1 \mathrm{H}, \mathrm{m}, \mathrm{H}-6), 3.41$ (2H, m, H-2, H-3), $2.53\left(2 \mathrm{H}, \mathrm{d}, J_{6,7}=5.6 \mathrm{~Hz}, \mathrm{H}-7\right) ;{ }^{13} \mathrm{C}-\mathrm{NMR}$ (DMSO- $\left.d_{6}\right) \delta(\mathrm{ppm})$ : 95.3 (C-1), 52.6 (C-2), 55.3 (C-3), 61.0 (C-4), 70.4 (C-4a), 66.8 (C-5), 69.6 (C-6), 42.9 (C-7), 198.8 (C-8), 62.9 (C-8a), 145.3 (C-1'), 109.1 (C-2'), 127.9 (C-3'), 120.8(C-4'), 133.8 (C-4a'), 120.7 (C-5'), $127.7\left(\mathrm{C}-6^{\prime}\right), 108.8\left(\mathrm{C}-7^{\prime}\right), 145.5\left(\mathrm{C}-8^{\prime}\right), 111.6\left(\mathrm{C}-8 \mathrm{a}^{\prime}\right)$. The structure was confirmed by comparison with the literature data [38].

Diepoxin $\gamma(6)$. White needle-like crystals $(\mathrm{MeOH})$; m.p. $176-178{ }^{\circ} \mathrm{C}$; UV (MeOH) $\lambda_{\max } 225,297,312$, and $327 \mathrm{~nm}$. The molecular formula $\mathrm{C}_{20} \mathrm{H}_{16} \mathrm{O}_{8}$ was determined by HR-ESI-MS $\mathrm{m} / \mathrm{z} 404.0738$ $\left([\mathrm{M}+\mathrm{Na}]^{+}\right.$, calcd for $\left.\mathrm{C}_{20} \mathrm{H}_{16} \mathrm{O}_{8} \mathrm{Na}, 404.0737\right) .{ }^{1} \mathrm{H}-\mathrm{NMR}$ (acetone- $\left.d_{6}\right) \delta(\mathrm{ppm}): 7.59\left(1 \mathrm{H}, \mathrm{d}, J_{3^{\prime}, 4^{\prime}}=\right.$ $\left.2.3 \mathrm{~Hz}, \mathrm{H}-4^{\prime}\right), 7.57\left(1 \mathrm{H}, \mathrm{d}, J_{5^{\prime}, 6^{\prime}}=2.3 \mathrm{~Hz}, \mathrm{H}-5^{\prime}\right), 7.52$ [1H, pseudo-t (dd), $J_{5^{\prime}, 6^{\prime}}=7.8 \mathrm{~Hz}$, $\left.J_{6^{\prime}, 7^{\prime}}=8.0 \mathrm{~Hz}, \mathrm{H}-3^{\prime}\right], 7.49$ [1H, pseudo-t $\left.(\mathrm{dd}), J_{5^{\prime}, 6^{\prime}}=7.8 \mathrm{~Hz}, J_{6^{\prime}, 7^{\prime}}=8.0 \mathrm{~Hz}, \mathrm{H}-6^{\prime}\right], 7.02(1 \mathrm{H}, \mathrm{d}$, $\left.J_{2^{\prime}, 3^{\prime}}=7.5 \mathrm{~Hz}, \mathrm{H}-2^{\prime}\right), 6.97\left(1 \mathrm{H}, \mathrm{d}, J_{6^{\prime}, 7^{\prime}}=7.6 \mathrm{~Hz}, \mathrm{H}-7^{\prime}\right), 4.97\left(1 \mathrm{H}, \mathrm{d}, J_{5,5-\mathrm{OH}}=7.0, \mathrm{OH}-5\right), 4.90$ (2H, br. s, OH-4, OH-6), 4.72 (1H, d, H-4), 4.22 (1H, d, H-5), 4.10 (1H, m, H-6), 3.47-3.48 (1H, m, H-3), 3.43 $\left(1 \mathrm{H}, \mathrm{d}, J_{2,3}=4.1, \mathrm{H}-2\right), 2.53-2.55(2 \mathrm{H}, \mathrm{m}, \mathrm{H}-7) ;{ }^{13} \mathrm{C}-\mathrm{NMR}$ (acetone- $\left.d_{6}\right) \delta(\mathrm{ppm}): 96.3(\mathrm{C}-1), 54.2(\mathrm{C}-2)$, 56.1 (C-3), 63.0 (C-4), 70.5 (C-4a), 67.2 (C-5), 63.2(C-6), 42.6 (C-7), 197.3 (C-8), 64.8 (C-8a), 146.7 (C-1'), 109.8 (C-2'), 128.6 (C-3'), 121.5 (C-4'), 135.2 (C-4a'), 121.5 (C-5'), 128.4 (C-6'), 109.5 (C-7'), 146.9 (C-8'), $113.0\left(\mathrm{C}-8 \mathrm{a}^{\prime}\right)$. The structure was confirmed by comparison with literature data [38].

\section{Conclusions}

The preparative separation of spirobisnaphthalenes from the endophytic fungus Berkleasmium sp. Dzf12 by classical methods is tedious, time consuming, and requires multiple chromatographic steps on silica gel, Sephadex LH-20, $\mathrm{C}_{18}$ reversed-phase silica gel, etc. [7]. In this work, six spirobisnaphthalenes, including diepoxin $\kappa(\mathbf{1})$, palmarumycin $\mathrm{C}_{13}$ (2), palmarumycin $\mathrm{C}_{16}$ (3), 
palmarumycin $\mathrm{C}_{15}(\mathbf{4})$, diepoxin $\delta(5)$, and diepoxin $\gamma(\mathbf{6})$, were successfully separated in one step from an endophytic fungus Berkleasmium sp. Dzf12 by HSCCC with a $n$-hexane-chloroform-methanol-water $(1.5: 3.0: 2.5: 2.0, \mathrm{v} / \mathrm{v})$ two-phase solvent system. This is the first report on the application of HSCCC for the separation of spirobisnaphthalenes from the cultures of endophytic fungus Berkleasmium $\mathrm{sp}$. Dzf12. If an HPLC method was used for preparative separation of spirobisnaphthalenes, diepoxin $\delta(5)$ and palmarumycin $\mathrm{C}_{16}$ (3) could not be separated (Figure 1). Moreover, the amounts of the spirobisnaphtalenes obtained by preparative HPLC were less than by HSCCC. The present study will provide a basis for a large preparation of spirobisnaphthalenes from endophytic fungus Berkleasmium sp. Dzf12, and also demonstrates that HSCCC is an efficient technique in preparatively separating bioactive compounds from fungi. More research work should be devoted to screening an alternative two-phase solvent system of HSCCC in order to shorten the time required to isolate the spirobisnaphthalenes.

\section{Acknowledgments}

This work was co-financed by the grants from the National Natural Science Foundation of China (31071710), the program for Changjiang Scholars and Innovative Research Team in University of China (IRT1042), and the Hi-Tech R\&D Program of China (2011AA10A202).

\section{Conflicts of Interest}

The authors declare no conflict of interest.

\section{References}

1. Cai, Y.-S.; Guo, Y.-W.; Krohn, K. Structure, bioactivities, biosynthetic relationships and chemical synthesis of the spirodioxynaphthalenes. Nat. Prod. Rep. 2010, 27, 1840-1870.

2. Zhou, L.; Zhao, J.; Shan, T.; Cai, X.; Peng, Y. Spirobisnaphthalenes from fungi and their biological activities. Mini Rev. Med. Chem. 2010, 10, 977-989.

3. Krohn, K.; Michel, A.; Florke, U.; Aust, H.-J.; Draeger, S.; Schulz, B. Palmarumycins $\mathrm{CP}_{1}-\mathrm{CP}_{4}$ from Coniothyrium palmarum: Isolation, structure elucidation, and biological activity. Liebigs Ann. Chem. 1994, 1994, 1093-1097.

4. Krohn, K.; Michel, A.; Florke, U.; Aust, H.-J.; Draeger, S.; Schulz, B. Palmarumycins $\mathrm{C}_{1}-\mathrm{C}_{16}$ from Coniothyrium sp.: Isolation, structure elucidation, and biological activity. Liebigs Ann. Chem. 1994, 1994, 1099-1108.

5. Hu, H.; Guo, H.; Li, E.; Liu, X.; Zhou, Y.; Che, Y. Decaspirones F-I, bioactive secondary metabolites from the saprophytic fungus Helicoma viridis. J. Nat. Prod. 2006, 69, 1672-1675.

6. Schlingmann, G.; West, R.R.; Milne, L.; Pearce, C.; Carter, G. Diepoxins, novel fungal metabolites with antibiotic activity. Tetrahedron Lett. 1993, 34, 7225-7228.

7. Cai, X.; Shan, T.; Li, P.; Huang, Y.; Xu, L.; Zhou, L.; Wang, M.; Jiang, W. Spirobisnaphthalenes from the endophytic fungus Dzf12 of Dioscorea zingiberensis and their antimicrobial activities. Nat. Prod. Commun. 2009, 4, 1469-1472. 
8. Bode, H.B.; Walker, M.; Zeeck, A. Secondary metabolites by chemical screening, 42. Cladospirones B to I from Sphaeropsidales sp. F-24'707 by variation of culture conditions. Eur. J. Org. Chem. 2000, 2000, 3185-3193.

9. Seephonkai, P.; Isaka, M.; Kittakoop, P.; Palittapongarnpim, P.; Kamchonwongpaisan, S.; Tanticharoen, M.; Thebtaranonth, Y. Evaluation of antimycobacterial, antiplasmodial and cytotoxic activities of preussomerins isolated from the lichenicolous fungus Microsphaeropsis sp. BCC 3050. Planta Med. 2002, 68, 45-48.

10. Dong, J.Y.; Song, H.C.; Li, J.H.; Tang, Y.S.; Sun, R.; Wang, L.; Zhou, Y.P.; Wang, L.M.; Shen, K.Z.; Wang, C.R.; et al. Ymf 1029A-E, preussomerin analogues from the fresh-water-derived fungus YMF 1.01029. J. Nat. Prod. 2008, 71, 952-956.

11. Martinez-Luis, S.; Della-Togna, G.; Coley, P.D.; Kursar, T.A.; Gerwick, W.H.; Cubilla-Rios, L. Antileishmanial constituents of the Panamanian endophytic fungus Edenia sp. J. Nat. Prod. 2008, 71, 2011-2014.

12. Chu, M.; Truumees, I.; Patel, M.G.; Gullo, V.P.; Blood, C.; King, I.; Pai, J.-K.; Puar, M.S. A novel class of antitumor metabolites from the fungus Nattrassia Mangiferae. Tetrahedron Lett. 1994, 35, 1343-1346.

13. Singh, S.B.; Zink, D.L.; Liesch, J.M.; Ball, R.G.; Goetz, M.A.; Bolessa, E.A.; Giacobbe, R.A.; Silverman, K.C.; Bills, G.F.; Pelaez, F.; et al. Preussomerins and deoxypreussomerins: Novel inhibitors of ras farnesyl-protein transferase. J. Org. Chem. 1994, 59, 6296-6302.

14. Sakemi, S.; Inagaki, T.; Kaneda, K.; Hirai, H.; Iwata, E.; Sakakibara, T.; Yamauchi, Y.; Norcia, M.; Wondrack, L.M.; Sutcliffe, J.A.; et al. CJ-12,371 and CJ-12,372, two novel DNA gyrase inhibitors. Fermentation, isolation, structural elucidation and biological activities. $J$ Antibiot. 1995, 48, 134-142.

15. Chu, M.; Truumees, I.; Patel, M.; Blood, C.; Das, P.R.; Puar, M.S. Sch 50673 and Sch 50676, two novel antitumor fungal metabolites. J. Antibiot. 1995, 48, 329-331.

16. Wipf, P.; Hopkins, T.D.; Jung, J.-K.; Rodriguez, S.; Birmingham, A.; Southwick, E.C.; Lazo, J.S.; Powis, G. New inhibitors of the thioredoxin-thioredoxin reductase system based on a naphthoquinone spiroketal natural product lead. Bioorg. Med. Chem. Lett. 2001, 11, 2637-2641.

17. Powis, G.; Wipf, P.; Lynch, S.M.; Birmingham, A.; Kirkpatrick, D.L. Molecular pharmacology and antitumor activity of palmarumycin-based inhibitors of thioredoxin reductase. Mol. Cancer Ther. 2006, 5, 630-636.

18. Li, Y.; Shan, T.; Mou, Y.; Li, P.; Zhao, J.; Zhao, W.; Peng, Y.; Zhou, L.; Ding, C. Enhancement of palmarumycin $\mathrm{C}_{12}$ and $\mathrm{C}_{13}$ production in liquid culture of endophytic fungus Berkleasmium $\mathrm{sp}$. Dzf12 by oligosaccharides from its host plant Dioscorea zingiberensis. Molecules 2012, 17, 3761-3773.

19. Zhao, J.; Zheng, B.; Li, Y.; Shan, T.; Mou, Y.; Lu, S.; Li, P.; Zhou, L. Enhancement of diepoxin $\zeta$ production by yeast extract and its fractions in liquid culture of Berkleasmium-like endophytic fungus Dzf12 from Dioscorea zingiberensis. Molecules 2011, 16, 847-856.

20. Zhao, J.; Li, Y.; Shan, T.; Mou, Y.; Zhou, L. Enhancement of diepoxin $\zeta$ production with in situ resin adsorption in mycelial liquid culture of the endophytic fungus Berkleasmium sp. Dzf12 from Dioscorea zingiberensis. World J. Microbiol. Biotechnol. 2011, 27, 2753-2758. 
21. Li, Y.; Li, P.; Mou, Y.; Zhao, J.; Shan, T.; Ding, C.; Zhou, L. Enhancement of diepoxin $\zeta$ production in liquid culture of endophytic fungus Berkleasmium sp. Dzf12 by polysaccharides from its host plant Dioscorea zingiberensis. World J. Microbiol. Biotechnol. 2012, 28, 1407-1413.

22. Mou, Y.; Luo, H.; Mao, Z.; Shan, T.; Sun, W.; Zhou, K.; Zhou, L. Enhancement of palmarumycins $\mathrm{C}_{12}$ and $\mathrm{C}_{13}$ production in liquid culture of endophytic fungus Berkleasmium sp. Dzf12 after treatments with metal ions. Int. J. Mol. Sci. 2013, 14, 979-998.

23. Zhao, J.; Shan, T.; Mou, Y.; Zhou, L. Plant-derived bioactive compounds produced by endophytic fungi. Mini Rev. Med. Chem. 2011, 11, 159-168.

24. Sannomiya, M.; Rodrigues, C.M.; Coelho, R.G.; dos Santos, L.C.; Hiruma-Lima, C.A.; Souza Brito, A.R.M.; Vilegas, W. Application of preparative high-speed counter-current chromatography for the separation of flavonoids from the leaves of Byrsonima crassa Niedenzu (IK). J. Chromatogr. A 2004, 1035, 47-51.

25. Wang, J.; Gao, H.; Zhao, J.; Wang, Q.; Zhou, L.; Han, J.; Yu, Z.; Yang, F. Preparative separation of phenolic compounds from Halimodendron halodendron by high-speed counter-current chromatography. Molecules 2010, 15, 5998-6007.

26. Gao, H.; Luo, C.; Wang, L.; Wang, J.; Zheng, B.; Peng, Y.; Zhou, L. Preparative separation of 3-O-methylkaempferol from Caragana leucophloea by high-speed counter-current chromatography and its antimicrobial activity. J. Med. Plants Res. 2012, 6, 2081-2087.

27. Tang, Q.; Liu, J.; Xue, J.; Ye, W.; Zhang, Z.; Yang, C. Preparative isolation and purification of two new isomeric diterpenoid alkaloids from Aconitum coreanum by high-speed counter-current chromatography. J. Chromatogr. B 2008, 872, 181-185.

28. Jerz, G.; Skotzki, T.; Fiege, K.; Winterhalter, P.; Wybraniec, S. Separation of betalains from berries of Phytolacca americana by ion-pair high-speed counter-current chromatography. J. Chromatogr. A 2008, 1190, 63-73.

29. Wang, J.; Wen, Y.; Chen, X.; Lin, Y.; Zhou, J.; Xie, Y.; Wang, H.; Jiang, H.; Zheng, W. Preparative separation of six antimycin A components from antimycin fermentation broth by high-speed counter-current chromatography. J. Chromatogr. A 2010, 1217, 5687-5692.

30. Gu, M.; Wang, X.; Su, Z.; Ouyang, F. One-step separation and purification of 3,4-dihydroxyphenyllactic acid, salvianolic acid B and protocatechualdehyde from Salvia miltiorrhiza Bunge by high-speed counter-current chromatography. J. Chromatogr. A 2007, 1140, 107-111.

31. Wu, H.; Su, Z.; Yang, Y.; Ba, H.; Aisa, H.A. Isolation of three sesquiterpene lactones from the roots of Cichorium glandulosum Boiss. et Huet. by high-speed counter-current chromatography. J. Chromatogr. A 2007, 1176, 217-222.

32. Peng, A.; Li, R.; Hu, J.; Chen, L.; Zhao, X.; Luo, H.; Ye, H.; Yuan, Y.; Wei, Y. Flow rate gradient high-speed counter-current chromatography separation of five diterpenoids from Triperygium wilfordii and scale-up. J. Chromatogr. A 2008, 1200, 129-135.

33. Zhao, J.; Mou, Y.; Shan, T.; Li, Y.; Lu, S.; Zhou, L. Preparative separation of helvolic acid from the endophytic fungus Pichia guilliermondii Ppf9 by high-speed counter-current chromatography. World J. Microbiol. Biotechnol. 2012, 28, 835-840.

34. Assimopoulou, A.N.; Sturm, S.; Stuppner, H.; Papageorgiou, V.P. Preparative isolation and purification of alkannin/shikonin derivatives from natural products by high-speed counter-current chromatography. Biomed. Chromatogr. 2009, 23, 182-198. 
35. Ito, Y. Golden rules and pitfalls in selecting optimum conditions for high-speed counter-current chromatography. J. Chromatogr. A 2005, 1065, 145-168.

36. Zhao, W.-H.; Gao, C.-C.; Ma, X.-F.; Bai, X.-Y.; Zhang, Y.-X. The isolation of 1,2,3,4,6-penta-Ogalloyl-beta-D-glucose from Acer truncatum Bunge by high-speed counter-current chromatography. J. Chromatogr. B 2007, 850, 523-527.

37. Li, F.-Y.; Gou, Z.-P.; Ma, X.-C.; Tian, Y.; Tian, G.; Wang, C.-Y.; Su, D.-H.; Liu, K.X.; Xin, X.-L. Preparative isolation and purification of two phyenylpropanoids from Daphne giraldii Nitsche by HSCCC. Chromatographia 2010, 71, 481-485.

38. Schlingmann, G.; Matile, S.; Berova, N.; Nakanishi, K.; Carter, G.T. Absolute stereochemistry of the diepoxins. Tetrahedron 1996, 52, 435-446.

Sample Availability: Samples of the spirobisnaphthalenes are available from the authors.

(C) 2013 by the authors; licensee MDPI, Basel, Switzerland. This article is an open access article distributed under the terms and conditions of the Creative Commons Attribution license (http://creativecommons.org/licenses/by/3.0/). 